Ambiente \& Água - An Interdisciplinary Journal of Applied Science
ISSN 1980-993X - doi:10.4136/1980-993X
www.ambi-agua.net
E-mail: ambi-agua@agro.unitau.br

\title{
Experimental plant for the physical-chemical treatment of groundwater polluted by Municipal Solid Waste (MSW) leachate, with ammonia recovery
}

\author{
doi: $10.4136 / a m b i-a g u a .1250$
}

Received: 29 Nov. 2013; Accepted: 13 Dec. 2013

\author{
Massimo Raboni ${ }^{1}$; Vincenzo Torretta ${ }^{1}$; Paolo Viotti ${ }^{2}$ Giordano Urbini $^{1}{ }^{*}$ \\ ${ }^{1}$ University of Insubria - Varese, Italy \\ Department of Biotechnologies and Life Sciences \\ ${ }^{2}$ University of Roma "La Sapienza"- Rome, Italy \\ Department of Hydraulics, Transportation and Roads \\ *Corresponding author: e-mail: giordano.urbini@tin.it, \\ massimo.raboni@uninsubria.it,vincenzo.torretta@uninsubria.it, \\ paolo.viotti@uniroma1.it
}

\begin{abstract}
The paper documents the results of the experimental treatment of groundwater (flow rate: $300 \mathrm{~m}^{3} \mathrm{~h}^{-1}$ ) polluted by the leachate of an old MSW landfill (7 million tonnes) in northern Italy. The process consists of a coagulation-flocculation pre-treatment at $\mathrm{pH}>11$, and subsequent ammonia stripping, after heating the water to $35-38{ }^{\circ} \mathrm{C}$ by means of the biogas produced by the landfill. The stripped ammonia was recovered by absorption with sulfuric acid, producing a $30 \%$ solution of ammonium sulfate, which was reused as a base fertilizer. In addition, the paper reports important operational aspects related to the scaling of the stripping tower's packing and its effect on $\mathrm{pH}$ and temperature profiles inside the towers caused by the closed loop, which recirculates the stripping air coming from the ammonia absorption towers with sulfuric acid. The average removal efficiency of ammonia reached $95.4 \%$ with an inlet mean concentration of $199.0 \mathrm{mg} \mathrm{L}^{-1}$.
\end{abstract}

Keywords: ammonia-stripping, landfill leachate, aquifer reclamation.

\section{Estação experimental para o tratamento físico-químico de águas subterrâneas poluídas por chorume de um aterro de resíduos sólidos urbanos, com recuperação de amônia}

\section{RESUMO}

O estudo relata os resultados de um tratamento experimental de águas subterrâneas (vazão: $300 \mathrm{~m}^{3} \mathrm{~h}^{-1}$ ) poluídas pelo chorume de um antigo aterro onde foram acondicionadas cerca de $7 \cdot 10^{6}$ toneladas de resíduos sólidos urbanos no norte da Itália. O processo de tratamento é constituído numa primeira etapa de coagulação-floculação a $\mathrm{pH}>11$, e subsequente remoção da amônia em torres de arraste após o aquecimento das águas residuais a 35-38 ${ }^{\circ} \mathrm{C}$ por meio do biogás do aterro. A amônia foi recuperada por absorção com o ácido sulfúrico, com a produção de uma solução a $30 \%$ de sulfato de amônia reutilizado como fertilizante de base. Neste artigo, são evidenciados importantes aspectos operacionais relacionados com a formação de incrustação nos materias de enchimento das torres de arraste e os efeitos sobre o $\mathrm{pH}$ e perfis de temperatura no interior das torres de arraste causados pelo 
circuito fechado de recirculação do ar vindo das torres de absorção de amônia com ácido sulfúrico. A eficiência média de remoção da amônia foi de 95,4\%, com uma concentração média de entrada de $199,0 \mathrm{mg} \mathrm{L}^{-1}$.

Palavras-chave: extração de amoníaco, aterro sanitário, remediação de aquíferos.

\section{INTRODUCTION}

Groundwater is the main source of drinking water in many areas of the world, mainly in Europe. For this reason, it is important to preserve its quality. The leachate of municipal solid waste (MSW) landfills is one of the major potential sources of groundwater pollution (Regadío et al., 2012). The most important contaminants present in MSW leachate are ammonia, organic compounds (represented by the COD) and heavy metals (Kjeldsen et al., 2002). For landfill leachate treatment, various biological and physical-chemical techniques are used and more often than not the integration of different techniques is needed due to the waste complexity (Renou et al., 2008). One of the biggest problems is the removal of the very high concentrations of ammonia $\left(400 \div 1200 \mathrm{mg} \mathrm{L}^{-1}\right)$ that remain stable throughout the life of the landfill, as opposed to other pollutants, which concentrations considerably change over time (Kjeldsen et al., 2002). Biological techniques for ammonia removal are widely used in the treatment of wastewaters with medium-low concentrations of this compound, such as domestic sewage (Raboni et al., 2013). This kind of process is somewhat limited in the treatment of leachate because of the very high concentrations of ammonia. However, some experiences are reported for biological treatment using a bio-filter (Fu et al., 2011), SBRsequencing batch reactor (Spagni and Marsili-Libelli, 2009), wetland (Sun et al., 2012) and ponds (Leite et al., 2011), especially for old landfill leachates. In the Italian context, it is common to subject the leachate to pre-treatment (in general coagulation-flocculation) and then send the effluent to a municipal sewage treatment plant.

The physical-chemical processes proposed for the removal of ammonia from the leachate are indeed numerous. Among them are: air stripping, precipitation as magnesium ammonium phosphate (struvite), photochemical and electrochemical processes, ion-exchange and membrane processes, chemical oxidation and adsorption (Martin et al., 2005; Rada et al., 2013; Renou et al., 2008; De Brito et al., 2010). Particular mention must be made of the stripping process, which involves several applications in full-scale plants, even if most of them are based on rudimentary techniques, in order to carry out even simple leachate pretreatments. Only in a few cases, the stripping process is the option for achieving a high ammonia removal efficiency and subsequent recovery (Kabdasli et al., 2000; Campos et al., 2013; Ferraz et al., 2013).

The experience reported in this paper is also based on a similar process, albeit applied to a very specific and unique situation. In fact, the experience concerns the treatment, with ammonia recovery, of groundwater contaminated by the leachate of an old municipal solid waste landfill located in an area north of Milan, Italy. Seven million tonnes of MSW were disposed in this landfill, without proper leachate control systems, before the first national legislation came into force in the field. The high COD, ammonia and other contaminants concentrations found in groundwater and their progressive migration enforced the remediation through pumping and treatment technology (Urbini and Conti, 2007), using five extraction-wells and a water treatment plant with the final effluent discharged to a nearby river. 


\section{MATERIALS AND METHODS}

\subsection{The treatment plant}

The physical-chemical plant for the treatment of polluted groundwater consisted of two parallel lines. Figure 1 presents the simplified schematic of the process.

Groundwater drawn from the three most contaminated wells $\left(Q=160 \mathrm{~m}^{3} \mathrm{~h}^{-1}\right)$ are first treated by coagulation-flocculation dosing $41 \%$ and $35 \%$ solutions of ferric chloride (dosage: $400 \mathrm{mg} \mathrm{L}^{-1}$, as $\mathrm{FeCl}_{3}$ ) and sodium hydroxide (dosage: $720 \mathrm{mg} \mathrm{L}^{-1}$, as $\mathrm{NaOH}$ ), respectively ( $\mathrm{pH}$ increase up to $\mathrm{pH}>11$ to convert the ion ammonium into free ammonia, in keeping with the subsequent stripping process). The chemicals' dosage was preliminary assayed in lab tests.

The additional possibility of dosing powdered activated carbon is an option in the event of strong peaks of COD in the water. The effluent produced by the coagulation-flocculation phase is heated to a temperature of $35-38{ }^{\circ} \mathrm{C}$ (by means of the landfill biogas) to improve the efficiency of ammonia stripping. The decision to carry out stripping using preheated water was determined by the need to achieve highly efficient ammonia removal in order to comply with the limit imposed by legislation for the final discharge in a nearby stream $\left(15 \mathrm{mg} \mathrm{L}^{-1}\right.$ of ammonia). The stripping air has a flow rate of $120,000 \mathrm{Nm}^{3} \mathrm{~h}^{-1}$ for each line and crosses the towers in countercurrent to the water.

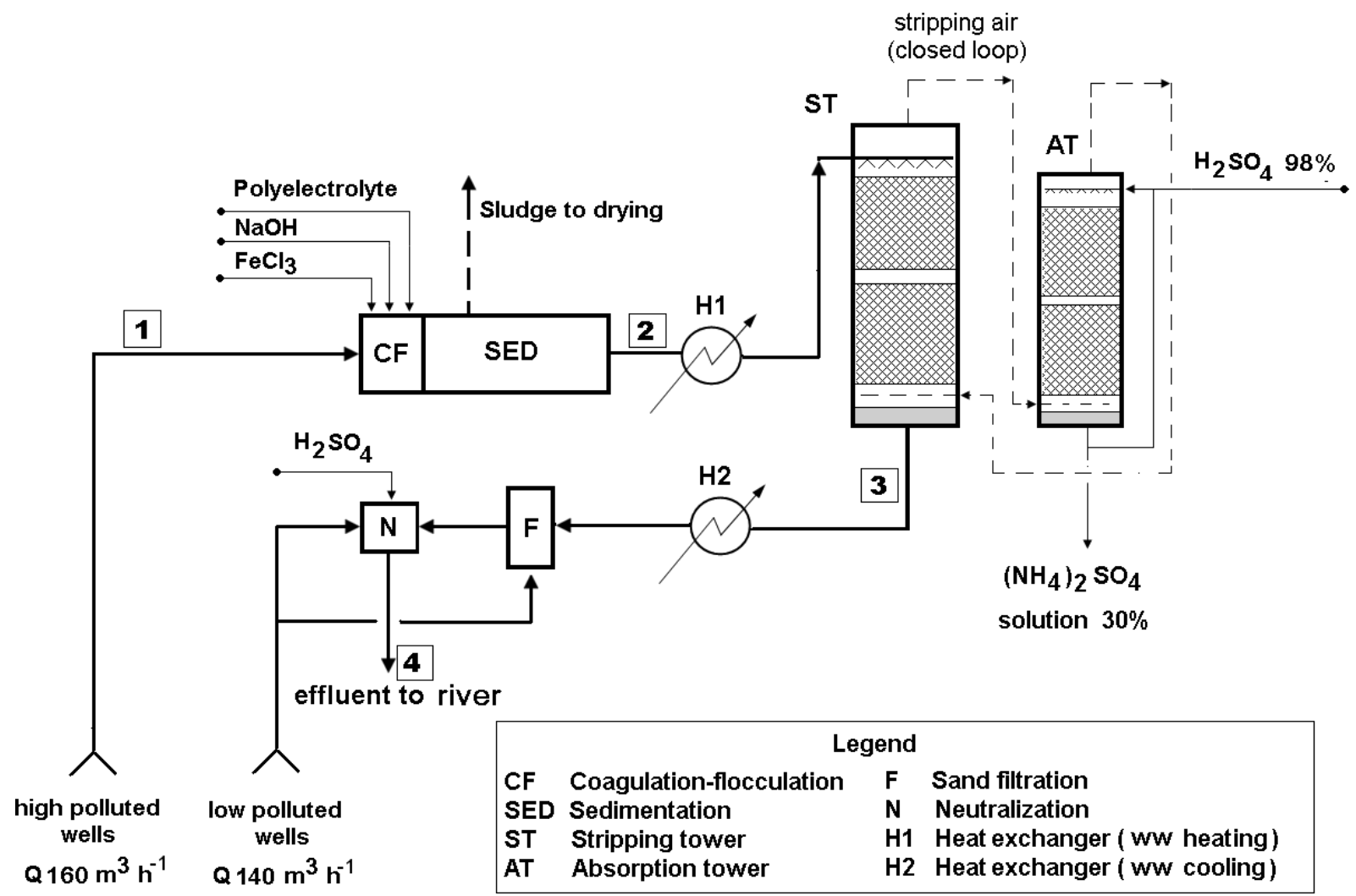

Figure 1. Schematization of the physical-chemical process for the treatment of polluted groundwater.

The two stripping towers (one tower per line), made of concrete, with an inner lining in polypropylene, have an internal diameter of $5.5 \mathrm{~m}$ and a $12 \mathrm{~m}$ packing height (Pall rings), divided into two consecutive stages to avoid excessive loads on the rings and the risk of crushing. 
All the plant operating conditions (e.g. water heating temperature, stripping air flow rate) and features (e.g. packing height) were defined during preliminary tests carried out on a small pilot plant.

The air leaving the stripping towers, enriched with ammonia, fed the absorption towers (two towers per line) made of polypropylene, with an internal diameter of $3.6 \mathrm{~m}$ and a $9 \mathrm{~m}$ packing height. A countercurrent recirculating absorbent solution containing sulfuric acid is fed to the air flow. The towers bottom flow consisted of a $30 \%$ ammonium sulfate solution (approximately 2,500 $\mathrm{kg} \mathrm{d}^{-1}$ as pure ammonium sulfate), which was reused as base fertilizer.

The air is therefore used in a closed circuit between the stripping and the absorption units. The effluent from the stripping towers was cooled with heat recovery and then filtered through sand beds prior to the final $\mathrm{pH}$ neutralization and discharge into the stream. Weakly contaminated groundwater $\left(Q=140 \mathrm{~m}^{3} \mathrm{~h}^{-1}\right)$ is fed through in this final stage of filtration and neutralization, giving the added benefit of reducing consumption of the neutralizing acid. In particular, the weakly contaminated groundwater quality was reported as follows: $\mathrm{COD}<20 \mathrm{mg} \mathrm{L}^{-1} ; \mathrm{NH}_{3}<6 \mathrm{mg} \mathrm{L}^{-1} ; \mathrm{Cl}^{-}<36 \mathrm{mg} \mathrm{L}^{-1} ; \mathrm{Fe}<1 \mathrm{mg} \mathrm{L}{ }^{-1} ; \mathrm{Ni}<0.031 \mathrm{mg} \mathrm{L}^{-1}$; $\mathrm{Zn}<0.070 \mathrm{mg} \mathrm{L}^{-1} ; \mathrm{Cu}<0.015 \mathrm{mg} \mathrm{L}^{-1} ; \mathrm{Pb}<0.010 \mathrm{mg} \mathrm{L}^{-1}$.

As stipulated by local regulations, the main quality target values for the final effluent are: $15 \mathrm{mg} \mathrm{L}^{-1}$ for ammonia; $120 \mathrm{mg} \mathrm{L}^{-1}$ for $\mathrm{COD} ; \mathrm{pH}$ in the range $5.5 \div 9.5$.

\subsection{Research main lines and analytical methods}

The research focused on two main aspects:

a) Checking the concentrations of the main pollution parameters of the groundwater fed into the physical-chemical process and the removal efficiency of the various stages of treatment. For this purpose, analytical determinations were carried out at the following sampling points (Figure 1): incoming highly polluted waters (1); output of pre-treatment (coagulation-flocculation) at $\mathrm{pH}>11$ (2); output of the stripping tower (3); final effluent sent to the water course (4). For each point, the following parameters were analyzed (three times a week), since significant results had been obtained during previous analytical groundwater tests: COD, ammonia, chloride, iron, nickel and zinc.

b) Checking the effects on the operation of the stripping towers where high values of $\mathrm{pH}$ and temperature occurred and also the effects of using air in a closed circuit. For this purpose, analytical determinations were carried out at points 1,2,3,4 for hardness and alkalinity in relation to the risk of precipitation and scaling. Scaling was assessed by measuring both its weight and composition on single packing elements. Furthermore, $\mathrm{pH}$ and temperature levels in the stripping towers were also measured at input and output to assess the effects of the closed loop air flow coming from the absorption tower with the sulfuric acid.

The monitoring campaign lasted for three months. For the various parameters analyzed, average daily values and deviation standards were obtained and shown in the illustrative graphs. Official standard methods approved by Italian law and developed by APAT IRSA CNR (2003) were adopted for sampling and analysis.

\section{RESULTS AND DISCUSSION}

\subsection{Performance of the plant with reference to the main pollution parameters}

Figure 2 shows the analytical results relating to the four points monitored on the plant. What appears to be particularly significant is the contamination of raw wastewaters by

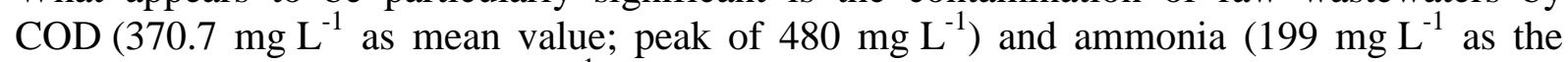
average value; peak of $340 \mathrm{mg} \mathrm{L}^{-1}$ ). Following the coagulation-flocculation phase, the COD shows an average 51\% decrease and there is a further, albeit small, removal in the stripping tower, which is believed to be caused partly by the transportation of volatile organic 
compounds in the air phase and partly by the oxidative action of oxygen on a few reducing compounds. The end stage (point 4) reduced the COD to an average level of $77.8 \mathrm{mg} \mathrm{L}^{-1}$.

Ammonia present in raw groundwater at an average concentration of $199 \mathrm{mg} \mathrm{L}^{-1}$ undergoes noticeable removal during the coagulation-flocculation step because of the high $\mathrm{pH}$, while, as expected, the most significant removal occurs during the stripping phase, where the outlet concentration drops to the mean value of $22.5 \mathrm{mg} \mathrm{L}^{-1}$ (average efficiency of 93\%). The final result (point 4) shows a reduction in ammonia concentration to an average level of $9.2 \mathrm{mg} \mathrm{L}^{-1}$.

Chloride occurs in raw water at an average concentration of $155.2 \mathrm{mg} \mathrm{L}^{-1}$, and undergoes a significant increase following the coagulation-flocculation stage because of the dosage of ferric chloride as coagulant reagent. The end result (point 4) raises chlorides to an average level of $210.4 \mathrm{mg} \mathrm{L}^{-1}$.

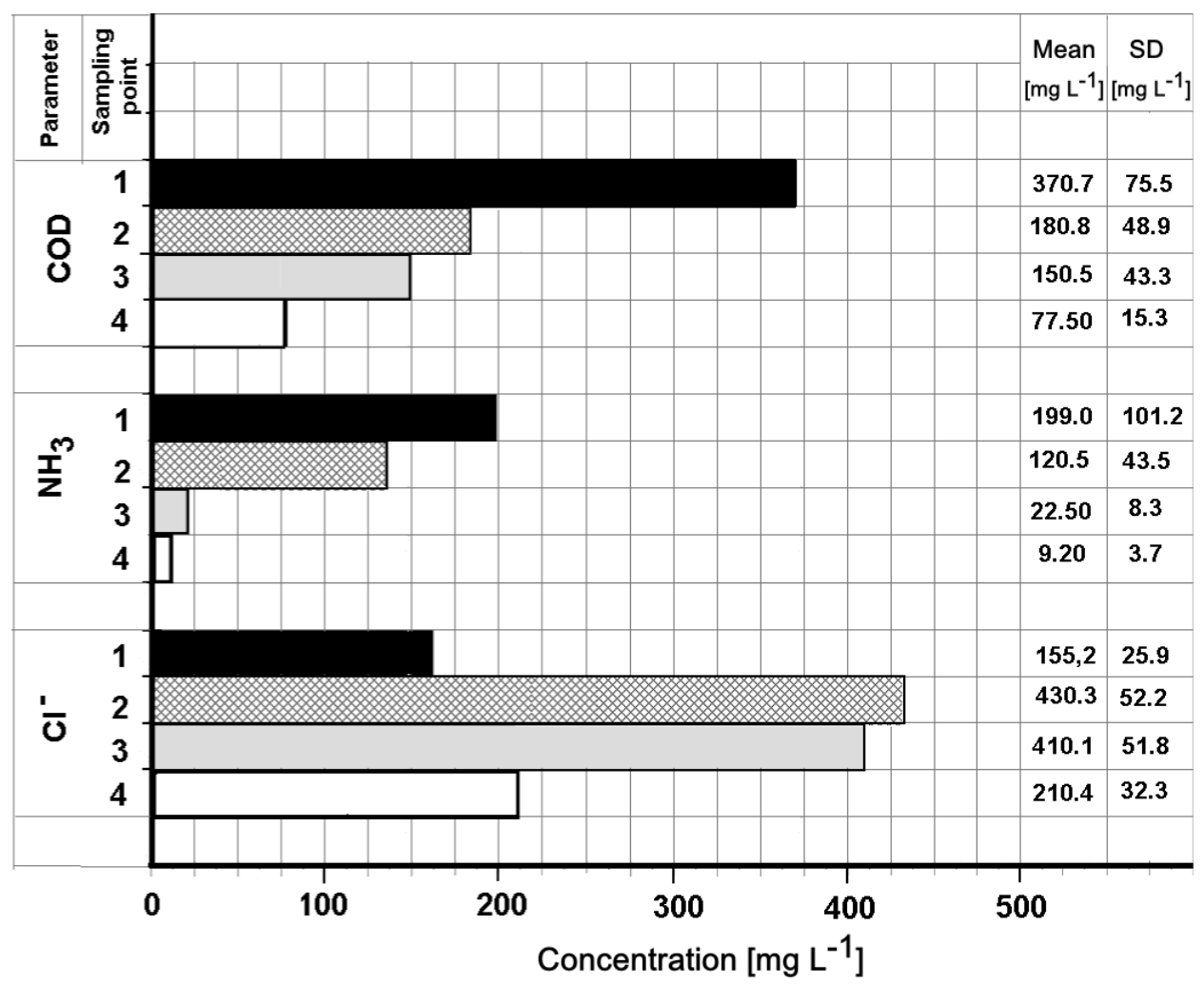

Figure 2. Concentrations of COD, ammonia and chloride at the four sampling points on the plant (average values and standard deviation).

With regard to the ammonia removal efficiency in the stripping towers, it should be noted that the two towers were prone to such severe scaling on the packing as to require periodic washing (every six months) with a $30 \%$ solution of hydrochloric acid. During operation periods with cleaned packing, efficiency reached average values of over $99 \%$ with average ammonia concentrations in the output of $4.1 \mathrm{mg} \mathrm{L}^{-1}$ (and peak values of $8.2 \mathrm{mg} \mathrm{L}^{-1}$ ).

As regards the metals (Figure 3), findings showed their progressive removal during the various stages of treatment, with obviously greater incidence during the initial stage of coagulation-flocculation at high $\mathrm{pH}$, when metals precipitate as hydroxides. A certain amount of removal was also detected in the stripping tower, which can be correlated to the formation of carbonate and hydroxide precipitates that were found in low concentrations in the scale on the packing. 


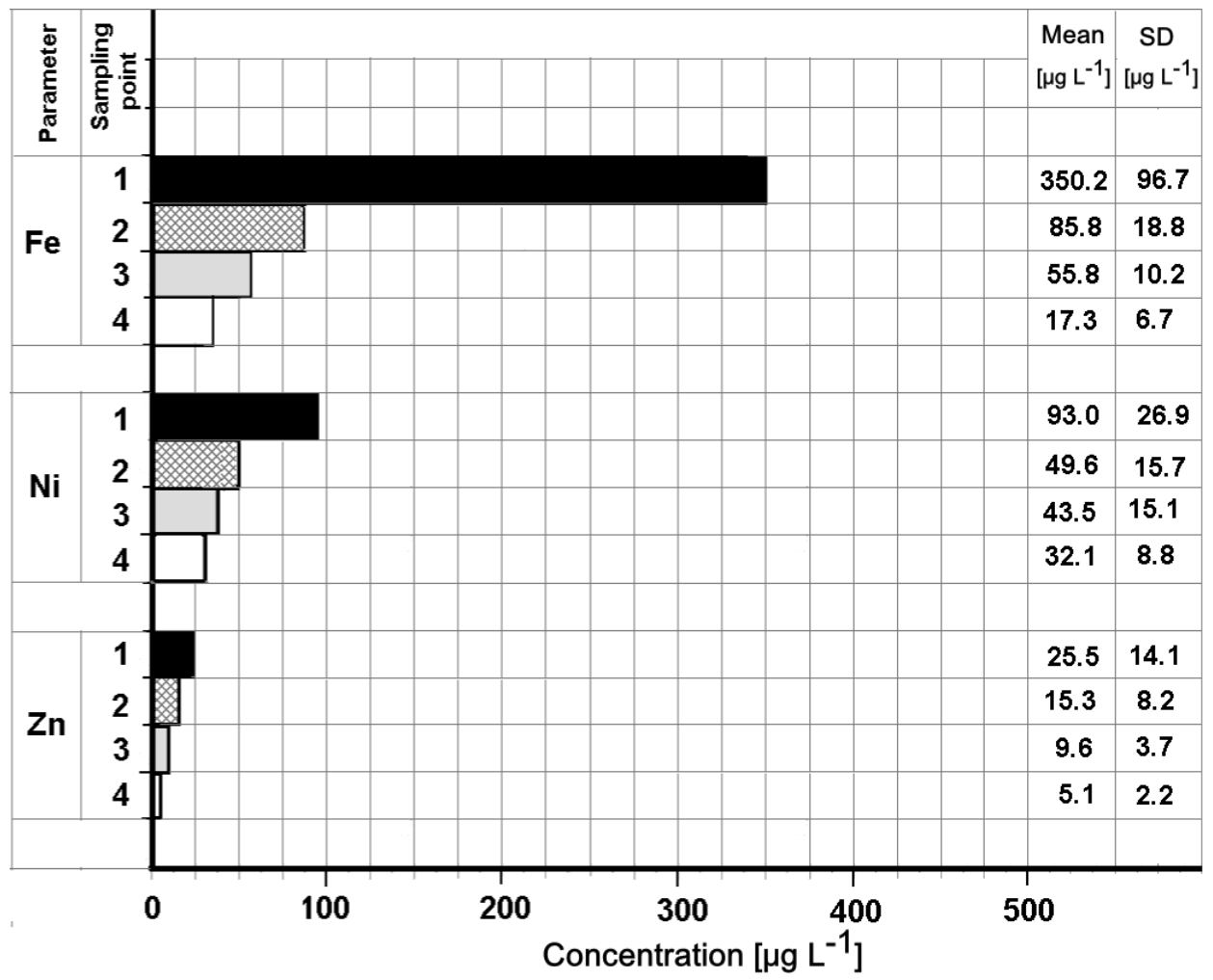

Figure 3. Concentrations of metals (iron, nickel and zinc) at the four sampling points of the plant (average values and standard deviation).

\subsection{Checking operating problems}

Lime scale coating the stripping tower packing was found to be the greatest operating problem (however, it also affected the first heat-exchanger for raising the temperature of the water). The progressive increase of scaling led to a loss of over $40 \%$ of the packing interfacial surface: the weight of each Pall rings increased approximately sevenfold (Figure 4).

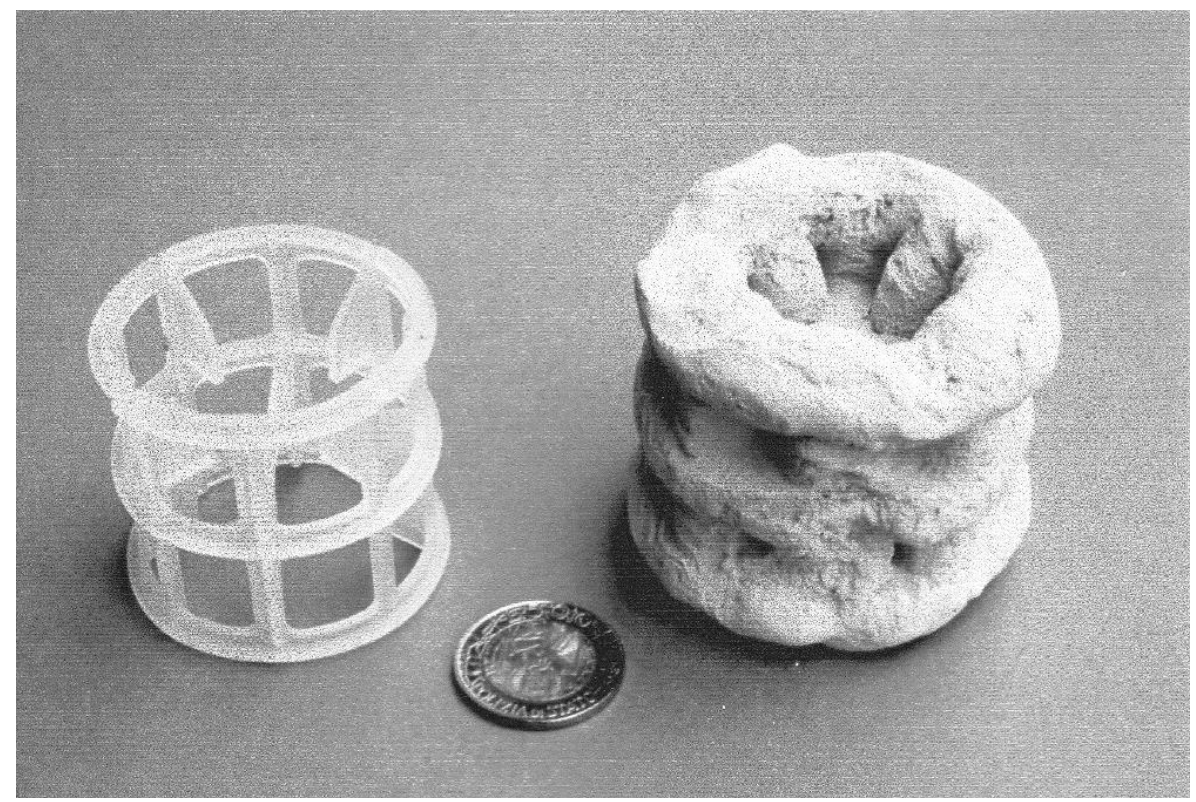

Figure 4. Single components (Pall ring) of the stripping towers packing, clean and at the highest degree of scaling. 
The scaling phenomenon is inevitably influenced by the temperature, but another important factor is the hardness and alkalinity parameters of the water. The graph in Figure 5 shows the values of these parameters at the four sampling points during the whole physical-chemical process.

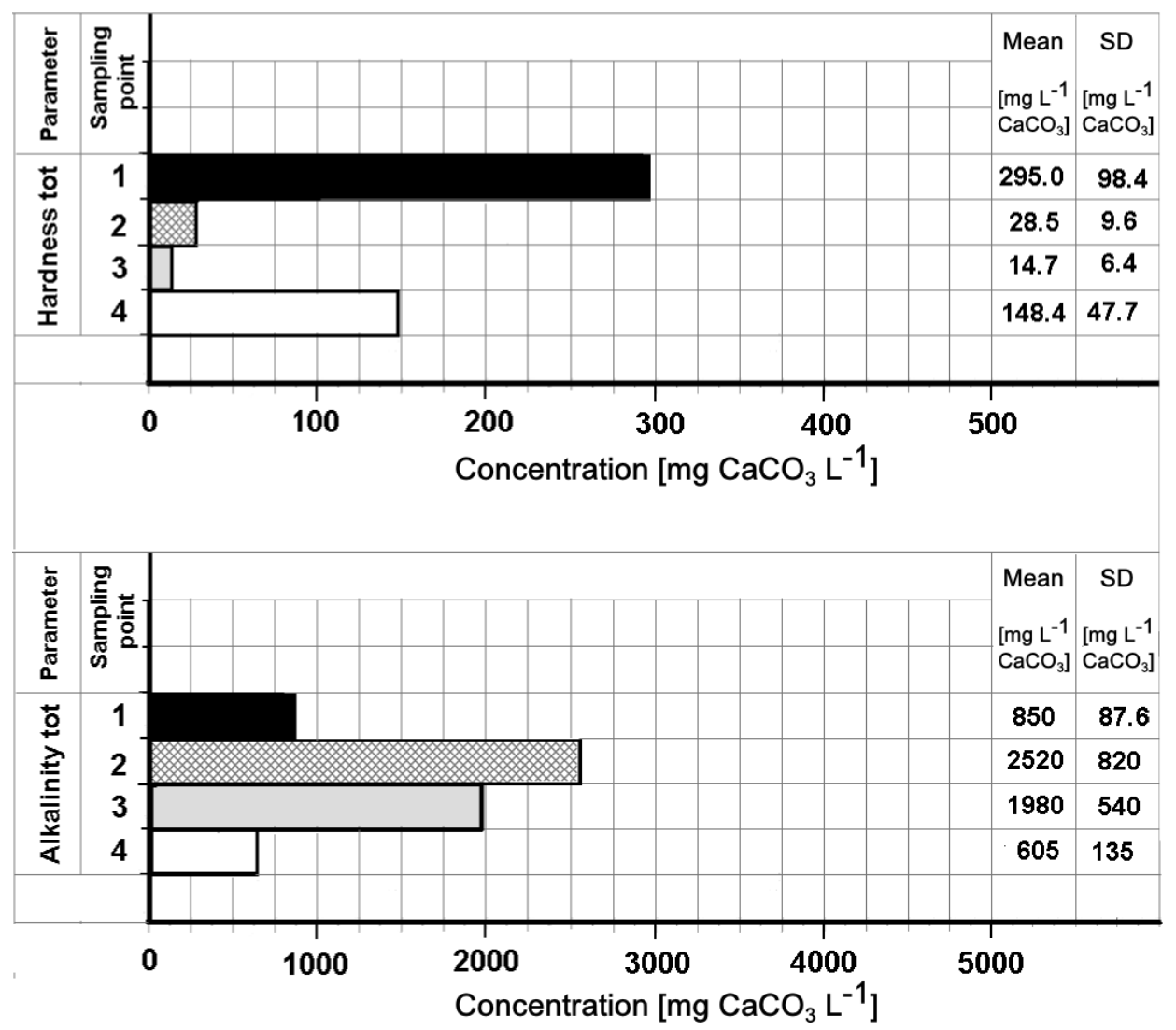

Figure 5. Concentrations of total hardness and total alkalinity at the four sampling points of the plant (average values and standard deviation).

The total hardness (consisting of approximately $90 \%$ of calcium hardness) present in the raw water at an average concentration of $295 \mathrm{mg} \mathrm{CaCO}_{3} \mathrm{~L}^{-1}$ undergoes a sharp reduction in the coagulation-flocculation stage. In fact, the high operating $\mathrm{pH}$ involves the precipitation of calcium carbonate and magnesium hydroxide, according to the following reactions:

$$
\begin{aligned}
& \mathrm{Ca}\left(\mathrm{HCO}_{3}\right)_{2}+2 \mathrm{NaOH} \rightarrow \mathbf{C a C O}_{3}+\mathrm{Na}_{2} \mathrm{CO}_{3}+2 \mathrm{H}_{2} \mathrm{O} \\
& \mathrm{Mg}\left(\mathrm{HCO}_{3}\right)_{2}+4 \mathrm{NaOH} \rightarrow \mathbf{M g}(\mathbf{O H})_{2}+2 \mathrm{Na}_{2} \mathrm{CO}_{3}+2 \mathrm{H}_{2} \mathrm{O} \\
& \mathrm{MgCl}_{2}+2 \mathrm{NaOH} \rightarrow \mathbf{M g}(\mathbf{O H})_{2}+2 \mathrm{NaCl}
\end{aligned}
$$

A further, albeit small, removal of total hardness occurs in the stripping stage due to chemical precipitation. The final concentration of $148.4 \mathrm{mg} \mathrm{CaCO}_{3} \mathrm{~L}^{-1}$ in the final effluent is merely the consequence of mixing it with poorly contaminated groundwater, whose total hardness is roughly $290 \div 340 \mathrm{mg} \mathrm{CaCO}_{3} \mathrm{~L}^{-1}$. As regards the formation of precipitates, a crucial role is played by the alkalinity of the water (mainly carbonatic) whose significant increase, as the result of increased $\mathrm{pH}$, leads to exceed the solubility product of calcium carbonate.

Total alkalinity shows appreciable removal in the stripping tower. This is not only due to the precipitation of carbonate salts and ammonia stripping, but also to the acidic character of 
stripping air coming from the absorption towers with sulfuric acid. This last effect was mitigated by an efficient demister with which all towers were equipped (even if it is impossible to avoid saturating the air flow with the acidic solution crossing the absorption towers). This phenomenon results in an average loss of about $0.6 \mathrm{pH}$ points in the water crossing the stripping, as shown in Figure 6. The same figure shows the trend of the average water temperature at the input and output of the towers.

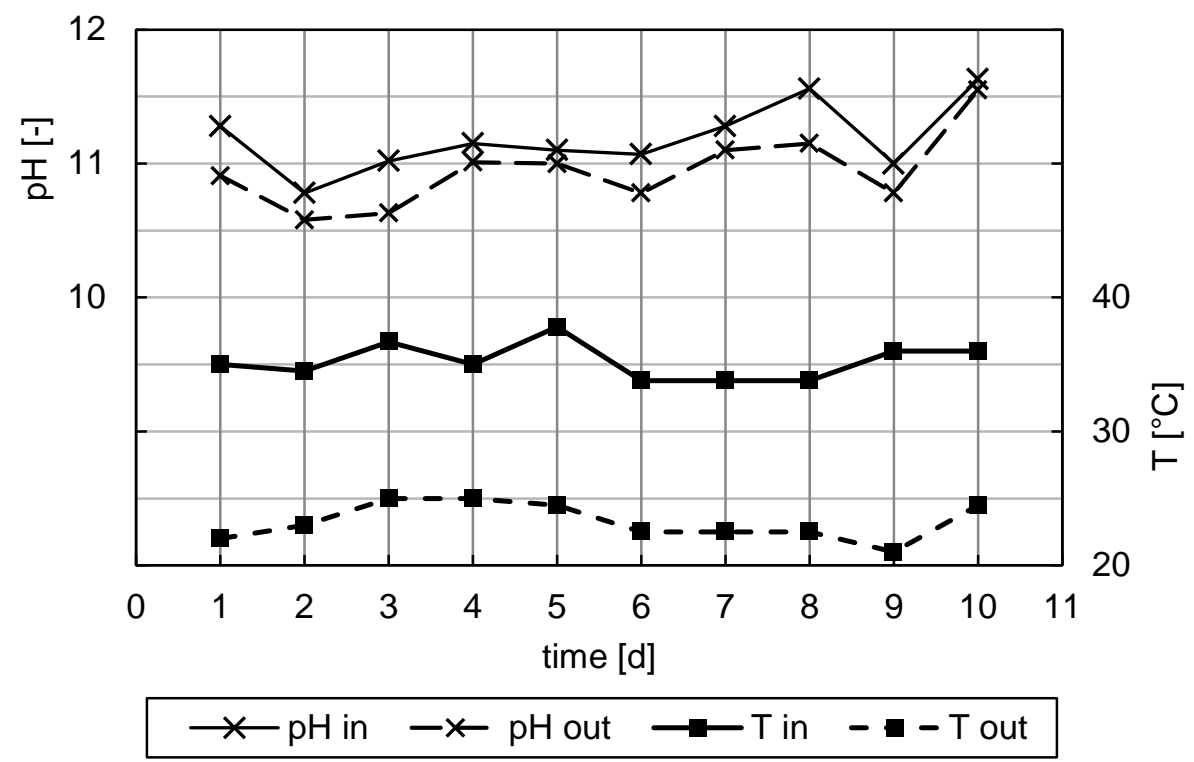

Figure 6. Variations of temperature and $\mathrm{pH}$ of the water crossing the stripping towers (10 measurements taken over two winter months).

The values of $\mathrm{pH}$ and temperature reported in Figure 6 refer to ten samplings carried out over a two-month period in winter. It was noted that the water crossing the stripping towers also undergoes a significant cooling effect from the mean value of $36.5^{\circ} \mathrm{C}$ (inlet) to an average value of $24.0^{\circ} \mathrm{C}$ (outlet) due to the stripping air flow.

It is worth observing that the "closed loop" of stripping air has the advantage of maintaining a stable temperature level for the same air and consequently for the water, especially in winter. The use of an "open" system utilizing ambient air for stripping would in fact lead to a more drastic drop in temperature and to the phenomena of "icing", considering that in winter the ambient air temperature may fall to $10-15^{\circ} \mathrm{C}$ below zero.

These phenomena (the lowering of $\mathrm{pH}$ and temperature) inevitably draw attention to the validity, or not, of a "closed loop" air system such as the one used in the plant for the stripping air, as compared with an "open" system that utilizes fresh air and disperses the air flow from the absorption tower into the atmosphere. This latter solution would eliminate the acidification effect in the stripping tower and would allow the stripping process to operate at a lower $\mathrm{pH}$ or at lower temperatures for the inlet water, with beneficial effects on scale formation, but it would also create an excessive drop in temperature in winter and a considerably negative impact on the efficiency of the stripping process, not to mention causing icing problems inside the towers.

\section{CONCLUSIONS}

The trials consisted of testing a physical-chemical plant for the treatment of groundwater contaminated by the leachate of an old MSW landfill without proper leachate control systems. Groundwater fed into the plant is drawn from five barrier wells, three of which are highly 
contaminated by ammonia (mean $199.0 \mathrm{mg} \mathrm{L}^{-1}$; peak of $340.0 \mathrm{mg} \mathrm{L}^{-1}$ ) and COD (mean $370.7 \mathrm{mg} \mathrm{L}^{-1}$; peak of $480.0 \mathrm{mg} \mathrm{L}^{-1}$ ) while the other two barrier wells are weakly contaminated (ammonia $<6 \mathrm{mg} \mathrm{L}^{-1}$; COD $<20 \mathrm{mg} \mathrm{L}^{-1}$ ). The whole process involves the treatment of the highly contaminated groundwater $\left(Q=160 \mathrm{~m}^{3} \mathrm{~h}^{-1}\right)$ by means of coagulationflocculation at $\mathrm{pH}>11$, heating at $35-38{ }^{\circ} \mathrm{C}$ (supported by landfill biogas) to favor the next phase of ammonia stripping in packed towers. Once stripped, ammonia is recovered in the absorption tower as a $30 \%$ solution of ammonium sulfate which is reused as a base fertilizer. The stripping air circulates between the stripping towers and the absorption towers in a "closed loop", i.e., without emission into the atmosphere. After the stripping stage, the water is subjected to cooling with heat recovery, sand filtration and final neutralization of $\mathrm{pH}$, with final discharge to a small watercourse. Weakly contaminated groundwater $\left(Q=140 \mathrm{~m}^{3} \mathrm{~h}^{-1}\right)$ is fed directly into the final stage of filtration-neutralization.

The experimental results demonstrate the ability of the plant to restore the pollution parameters in accordance with the limits of acceptability for the discharge into surface watercourses, as stated by local regulations (COD: $120 \mathrm{mg} \mathrm{L}^{-1}$; ammonia: $15 \mathrm{mg} \mathrm{L}^{-1}$; $\mathrm{pH}$ : $5.5 \div 9.5)$. In particular, the COD plummets from the mean value of $370.7 \mathrm{mg} \mathrm{L}^{-1}$ in raw waters to $77.5 \mathrm{mg} \mathrm{L}^{-1}$ in the final effluent. Similarly, ammonia is reduced from $199.0 \mathrm{mg} \mathrm{L}^{-1}$ to $9.20 \mathrm{mg} \mathrm{L}^{-1}$. Moreover, the main metals (e.g. Fe, $\mathrm{Zn}, \mathrm{Ni}$ ) undergo adequate removal.

The experiment also highlighted important operational aspects related to the progressive scaling (predominantly limestone) of stripping packing materials (Pall rings) with a loss of more than $40 \%$ of the interfacial surface and an increase in weight of up to 7 times the initial weight (clean Pall rings). One cause of this phenomenon is the high water temperature, but additional factors are the high values of water total hardness and alkalinity. To avoid excessive removal efficiency losses, the packing is periodically washed (every six months) with a $30 \%$ solution of hydrochloric acid. A further operational problem that came to light is the noticeable drop in the $\mathrm{pH}$ of water while crossing the stripping tower. This is caused not only by the loss of ammonia and limestone precipitation, but also by the acidic character of the recirculated process air fed into the stripping towers. This phenomenon results in an approximate 0.6 point reduction in $\mathrm{pH}$, without which it is believed that less drastic operating conditions in terms of $\mathrm{pH}$ and temperature could be used. In this sense, attention should be given to finding a solution for ammonia recovery by using air in an open circuit, i.e., with the use of ambient air for the stripping phase. However, results show that the closed-loop air system adopted in the experimental plant allows a water temperature of $24.0 \div 36.5^{\circ} \mathrm{C}$ into the stripping towers during winter (also with outside temperatures of $-15^{\circ} \mathrm{C}$ ), whereas the open system would lead to drastic reductions in temperature in the towers with significant losses of efficiency and the risk of icing.

\section{ACKNOWLEDGMENTS}

This research was supported by the Research Funds of the Insubria University, Varese, Italy.

\section{REFERENCES}

AGENCY FOR THE ENVIRONMENTAL PROTECTION AND TECHNICAL SERVICES - APAT; WATER RESEARCH INSTITUTE - IRSA; NATIONAL RESEARCH COUNCIL - CNR (Italy). Analytical methods for waters - vol. I. Rome, 2003 1160p.(Handbook and Guidelines, 29/2003) 
CAMPOS, J. C.; MOURA, D.; COSTA, A. P.; YOKOYAMA, L.; ARAUJO, F. V. D. F.; CAMMAROTA, M. C. et al. Evaluation of $\mathrm{pH}$, alkalinity and temperature during air stripping process for ammonia removal from landfill leachate. J. Environ. Sci. Heal. A, v. 48, n. 9, p. 1105-1113, 2013. http://dx.doi.org/10.1080/10934529.2013.774658

DE BRITO, N. N.; STIPP PATERNIANI, J. E.; BROTA, G. A.; TEIXERA PELLEGRINI, R. Ammonia removal from leachate by photochemical process using $\mathrm{H}_{2} \mathrm{O}_{2}$. Rev. Ambient. Água, v. 5, n. 2, p. 51-60, 2010. http://dx.doi.org/10.4136/ambi-agua.136

FERRAZ, F. M.; POVINELLI, J.; VIEIRA, E. M. Ammonia removal from landfill leachate by air stripping and absorption. Environ. Technol., v. 34, n. 15, p. 2317-2326, 2013. http://dx.doi.org/10.1080/09593330.2013.767283

FU, J.; SHANG, J.; ZHAO, Y. Simultaneous removal of iron, manganese and ammonia from groundwater in single biofilter layer using BAF. Adv. Mat. Res., v. 183-185, p. 442-446, 2011. http://dx.doi.org/10.4028/www.scientific.net/AMR.183-185.442

KABDASLI, I.; TÜNAY, O.; ÖZTÜRK, I.; YILMAZ, S.; ARIKAN, O. Ammonia removal from young landfill leachate by magnesium ammonium phosphate precipitation and air stripping. Water Sci. Technol., v. 41, n. 1, p. 237-240, 2000.

KJELDSEN, P.; BARLAZ, M. A.; ROOKER, A. P.; BAUN, A.; LEDIN, A.; CHRISTENSEN, T. H. Present and long-term composition of MSW landfill leachate: A review. Crit. Rev. Env. Sci. Tec., v. 32, n. 4, p. 297-336, 2002. http://dx.doi.org/10.1080/10643380290813462

LEITE, V. D.; PEARSON, H. W.; DE SOUSA, J. T.; LOPES, W. S.; DE LUNA, M. L. D. The removal of ammonia from sanitary landfill leachate using a series of shallow waste stabilization ponds. Water Sci. Technol., v. 63, n.4, p. 666-670, 2011. http://dx.doi.org/10.2166/wst.2011.103

MARTIN, A.; LUCK, F.; ARMBRUSTER, U.; PATRIA, L.; RADNIK, J.; SCHNEIDER, M. Ammonia removal from effluent streams of wet oxidation under high pressure. Top. Catal., v. 33, n. 1-4, p. 155-169, 2005. http://dx.doi.org/10.1007/s11244-005-2522-4

RABONI, M.; TORRETTA, V.; URBINI, G. Influence of strong diurnal variations in sewage quality on the performance of biological denitrification in small community wastewater treatment plants (WWTPs). Sustainability, v. 5, n. 9, p. 3679-3689, 2013. http://dx.doi.org/10.3390/su5093679

RADA, E. C.; ISTRATE, I. A.; RAGAZZI, M.; ANDREOTTOLA, G.; TORRETTA, V. Analysis of electro-oxidation suitability for landfill leachate treatment through an experimental study, Sustainability, v. 5, n. 9, p. 3960-3975, 2013. http://dx.doi.org/10.3390/su5093960

REGADÍO, M.; RUIZ, A. I.; DE SOTO, I. S.; RODRIGUEZ RASTRERO, M.; SÁNCHEZ, N.; GISMERA, M. J.; Sevilla, M. T. et al. Pollution profiles and physicochemical parameters in old uncontrolled landfills. Waste Manage., v. 32, n.3, p. 482-497, 2012. http://dx.doi.org/10.1016/j.wasman.2011.11.008

RENOU, S.; GIVAUDAN, J. G.; POULAIN, S.; DIRASSOUYAN, F.; MOULIN, P. Landfill leachate treatment: Review and opportunity. J. Hazard. Mater., v. 150, n. 3, p. 468493, 2008. http://dx.doi.org/10.1016/j.jhazmat.2007.09.077 
SPAGNI, A.; MARSILI-LIBELLI, S. Nitrogen removal via nitrite in a sequencing batch reactor treating sanitary landfill leachate. Bioresource Technol., v. 100, n. 2, p. 609-614, 2009. http://dx.doi.org/10.1016/j.biortech.2008.06.064

SUN, G.; ZHU, Y.; SAEED, T.; ZHANG, G.; LU, X. Nitrogen removal and microbial community profiles in six wetland columns receiving high ammonia load. Chem. Eng. J., v. 203, p. 326-332, 2012. http://dx.doi.org/10.1016/j.cej.2012.07.052

URBINI G.; CONTI F. Chemico-physical treatment of groundwater polluted by landfill leachate (in Italian). In: REMEDIATION TECHNOLOGY CONFERENCE \& EXHIBITION, 1, 26-28 Sept. 2007, Ferrara. Proceedings... Ferrara, 2007. p. 1-17. 